\title{
Water quality for triathlon and open water swimming competitions in Brazilian freshwaters
}

\author{
Frederico Azevedo Lopes*, Andrea Coelho Leite
}

Federal University of Minas Gerais (UFMG), Av. Antônio Carlos 6627, Belo Horizonte, Brazil, e-mail: fredericolopes@ufmg.br (F.A.L., "corresponding author)

\begin{abstract}
In high-performance competitive activities, there can be intense and prolonged exposure to water during swimming components of the competition. Therefore, water quality assessments with reference to standards are desirable to ensure athletes' health. We evaluated whether the official criteria established for primary contact recreation in Brazilian freshwaters (CONAMA Directive 274/2000), and an integrated index of bathing conditions in Brazil (ICB), are consistent with the water quality standards stipulated by the International Triathlon Union (ITU). The water quality of Lake of Ingleses, an important venue for triathlon and open water swimming near Belo Horizonte, Minas Gerais, Brazil, was assessed between 2003 and 2019. Results for $E$. coli, cyanobacteria density, and $\mathrm{pH}$ were favorable for contact recreation and competitions at the lake. Of the variables considered, only turbidity, used as a proxy indicator of visual water clarity, was unsuitable during part of the monitoring period. The ICB agreed with the ITU standards for Very Good and Excellent quality classes and is recommended as a tool for screening sites considered for competitions in Brazilian freshwaters. However, the Brazilian national criteria for contact recreation only present standards for $E$. coli and $\mathrm{pH}$, which is insufficient coverage of attributes affecting primary contact suitability of water in high-performance sports activities.
\end{abstract}

Key words: water quality, contact recreation, triathlon, open water swimming, health risk

\section{Introduction}

Recreational water use, including contemplative leisure, fishing, navigation, and primary contact with waters, has historically been important throughout the development of human society (Lopes and Jesus 2017). Water-based recreation provides recognized physical and mental health benefits (Foley 2017; Massey et al. 2020). Swimming activities in open waters (rivers, lakes, and the sea) have grown in popularity recently, even in areas considered unsuitable for primary contact recreation (Hall et al. 2017).

Recreational, natural waters present varying concentrations of pathogenic and non-pathogenic faecal microorganisms from domestic, industrial, agricultural (livestock) and wildlife sources. Additionally, faecal contamination may be produced in situ by bathers themselves (WHO 2001; Fewtrel and Kay 2015). Thus, diseases associated with primary contact recreation in water bodies is a risk factor for human health (Pruss 1998; Zmirou 2003; Yau et al. 2009; Soller et al. 2010; Lamparelli et al. 2015; Mannocci et al. 2016).

Bathers' behaviour, and the nature of recreational practice in waters, is an important consideration for determining the risks to human health, given the possibility of total or partial body immersion, duration of exposure, and consequent volume of water ingested (Dufour et al. 2017). Intensive water primary contact activities, such as long open water swimming and triathlon competitions, can be considered relatively high risk for swimmers. The dominant factors for triathletes are long exposure time and the ingestion of significant volumes of water (Medema et al. 1997). Additionally, triathletes could be even more susceptible to infection due to temporary suppression of the immune response associated with high-intensity exercise (Dallam et al. 2005; Migliorini 2019). Thus, even in areas where water quality complies 
with established standards, triathletes are more likely to contract gastroenteritis compared to non-swimmers (Van Asperen et al. 1998).

According to Dufour et al. (2017), water ingestion by swimmers has been estimated since the early 1950s. However, the first empirical studies, through the detection in the swimmers' urine of cyanuric acid $(\mathrm{CNOH})_{3}$ used in the disinfection of swimming pools, were developed only in the 1980 s, and more recently by Dufour et al. (2006, 2017), Dorevitch et al. (2011) and Suppes et al. (2014). In addition to the faecal-oral route of transmission, diseases associated with waterbased recreational activities can be contracted by contact via eyes, ears, nasal cavity, and upper respiratory tract (WHO 2001).

Swimming suitability is also known to be affected by other water quality attributes, such as cyanobacteria density, $\mathrm{pH}$ and visual attributes such as visual clarity (Lopes et al. 2016). Toxins produced by cyanobacteria can produce a range of adverse health effects as skin irritations, stomach upsets and death (Chorus and Bartram 1999; Carmichael et al. 2001; Codd et al. 2005). Extreme $\mathrm{pH}$ values may result in skin and eye irritation (WHO 2003). Visual clarity is an important variable affecting identification and perception of depth and avoidance of risks, such as submerged hazards (e.g., litter), by bathers, in addition to affecting aesthetic amenity (Lopes et al. 2016; West et al. 2016; Davies-Colley et al. 2018).

Therefore, competitive swimming needs to be regulated by the establishment of specific water quality standards and monitoring programs (e.g., USEPA 1986; CONAMA 2000; WHO 2000; MFE/MOH 2003; EU 2006). In Brazil, criteria for assessing water quality for contact recreation were established by CONAMA Directive $274 / 2000$. The quality of recreational freshwater is classified according to the concentrations of thermotolerant faecal coliforms or Escherichia coli and pH. This directive has also been adopted by the state of Minas Gerais, together with cyanobacteria density standards (COPAM/CERH-MG 2008). However, Brazil lacks recreational standards to protect against the risk of submerged hazards in the water body and the perception of depth that are adversely affected by low visibility.

Recreational use of waters in Brazil is widely recognized for its social and economic importance. This includes national and international open water sports competitions (e.g., triathlon and open-water swimming). Therefore, standards for contact recreation in Brazilian freshwaters (CONAMA 2000), and the Index of Conditions for
Bathing (ICB: Lopes et al. 2016), need to be consistent with the criteria and standards stipulated by the International Triathlon Union (ITU), as regards swimming competitions in open-waters in Brazil. Lake of Ingleses, located in the metropolitan region of Belo Horizonte, is the main area for high performance water-based sports in the state of Minas Gerais. This paper presents an assessment of contact recreational suitability for highperformance water-based sports based on official state water quality monitoring data collected between 2003 and 2019, and an evaluation whether the official criteria established for primary contact recreation in Brazilian freshwaters (CONAMA Directive 274/2000), and an integrated index of bathing conditions in Brazil (ICB), are consistent with the water quality standards stipulated by the International Triathlon Union (ITU).

\section{Methods}

\section{Study area}

The Lake of Ingleses is located in the municipality of Nova Lima, within the Metropolitan Region of Belo Horizonte, the third largest in Brazil, with an estimated population of 5.9M (Fig. 1). Located only $35 \mathrm{~km}$ from the city of Belo Horizonte (capital of the state), the study area is part of the das Velhas River basin, an important river in Southeast Brazil. This river is used as the main water supply for the metropolitan region, and there have been efforts to improve general water quality in the basin in order to achieve recreational water standards for swimming and fishing (Meta 2014).

The Lake of Ingleses (or Lake Grande) is an impoundment constructed in 1932, mainly for the purpose of producing electricity for the extraction of gold from the Morro Velho mine by an Englishowned company (Villaschi 2003). Currently, the lake is surrounded by gated communities, designed to house services, commerce, leisure activities, with the purpose of attracting people who wish to escape from the conurbation of Belo Horizonte (Laschefski and Costa 2008). The lake waters have been used for numerous activities, including canoeing, scuba diving, sailing, stand-up paddleboarding, and triathlon - open water swimming competitions.

The climate is high-altitude tropical (Cwa, according to Köppen), with dry winters and rainy summers. The average temperature is $23.3^{\circ} \mathrm{C}$, and the annual total rainfall ranges 1,500-1,600 $\mathrm{mm}$ per year. The vegetation is transitional between Atlantic Forest and Brazilian Savanna, with 
Eucalyptus sp. plantings surrounding the Lake (CSUL 2015).

\section{Assessment of water quality}

Water quality data between January 2003 and July 2019 were obtained from the official monitoring program of the state of Minas Gerais, "Águas de Minas", available through the InfoHidro Portal (IGAM 2020). The monitoring is carried out at a single sampling station (AV160), implemented in January 2003, with quarterly frequency (2003 and 2004) and biannual (from 2006 to present). There are no data available for the year 2005, and monitoring data for cyanobacteria are available from 2008.

We selected the water quality attributes stipulated by the International Triathlon Union (ITU), for open-freshwater swimming competitions (Migliorini 2019), measured in the official state monitoring program. Additionally, the attributes adopted by the Index of Conditions for Bathing (ICB: Lopes et al. 2016), for contact recreation in Brazilian freshwaters, and the official criteria for contact recreation in Brazil, established by CONAMA Directive 274/2000, were collated (Table 1 ).

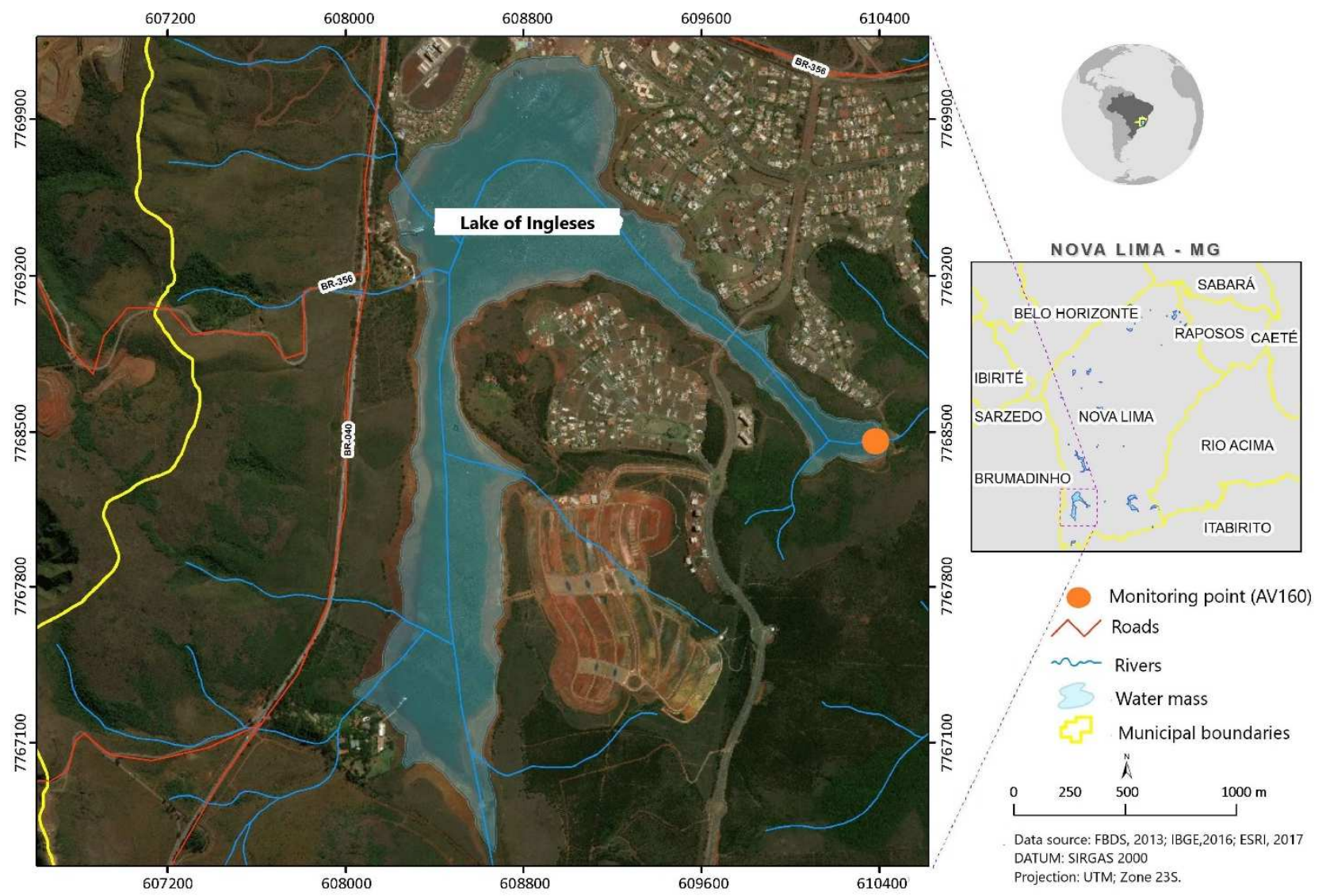

Fig. 1. Location of Lake of Ingleses - Minas Gerais state - Southeast Brazil

Table 1. Water quality criteria and standards for contact recreation in Brazilian freshwaters and swimming competitions by International Triathlon Union (ITU). Adapted from CONAMA (2000), Lopes et al. (2016), and Migliorini (2019)

\begin{tabular}{|c|c|c|c|c|c|c|c|}
\hline \multirow{2}{*}{ Attribute } & \multirow{2}{*}{ ITU } & \multicolumn{3}{|c|}{ CONAMA Directive 274/2000 } & \multicolumn{3}{|c|}{ Index of Conditions for Bathing. ICB } \\
\hline & & Suitable & Very Good & Excellent & Suitable & Very Good & Excellent \\
\hline Escherichia coli [cfu $100 \mathrm{~cm}^{-3}$ ] & 500 & 800 & 400 & 200 & 800 & 400 & 200 \\
\hline Cyanobacteria density [cells $\mathrm{cm}^{-3}$ ] & 100,000 & - & - & - & 10,000 & 5,000 & 500 \\
\hline $\mathrm{pH}$ & $6-9$ & $6-9$ & - & - & $6-9$ & $6.5-8.5$ & $7-8$ \\
\hline $\begin{array}{l}\text { Turbidity [NTU] } \\
\text { (visibility, aprox.) }\end{array}$ & - & - & - & - & $\begin{array}{c}10^{*} \\
(0.3 \mathrm{~m})\end{array}$ & $\begin{array}{c}5 \\
(0.8 \mathrm{~m})\end{array}$ & $\begin{array}{c}2 \\
(1.5 \mathrm{~m})\end{array}$ \\
\hline Visual clarity [Secchi depth in $\mathrm{m}$ ] & $\geq 1$ & - & - & - & - & - & - \\
\hline
\end{tabular}

${ }^{*}$ ICB uses turbidity as an indirect measure of visual clarity [m] 
The ICB includes cyanobacteria density levels, in compliance with a state Directive COPAM/CERH 01/2008 (COPAM/CERH-MG 2008). Despite the absence of official criteria for visual clarity in recreational waters in Brazil, the standards proposed by the ICB were adopted. Visual clarity is an important variable affecting identification and perception of depth and avoidance of risks, such as submerged hazards, by bathers - in addition to affecting aesthetic amenity (Lopes et al. 2016). In the absence of visibility measurements in official monitoring, turbidity was used as a rough proxy for visual clarity.

Total available data, include the variables: $E$. coli ( $\mathrm{n}=34)$, cyanobacteria density $(\mathrm{n}=23), \mathrm{pH}(\mathrm{n}=$ $35)$ and turbidity $(n=35)$, recorded between December 2003 and December 2019 (17 years).

According to the CONAMA Directive 274/ 200, freshwaters considered adequate for primary contact recreation are subdivided into "Excellent" (E. coli $\left.\leq 200 \mathrm{cfu} 100 \mathrm{~cm}^{-3}\right)$, "Very good" (E. coli $\leq$ $400 \mathrm{cfu} 100 \mathrm{~cm}^{-3}$ ) and "Satisfactory" (E. coli $\leq 800$ cfu $100 \mathrm{~cm}^{-3}$ ). However, this classification is based on the criteria of $80 \%$ of the results of a minimum set of 5 samples, collected weekly, implying a sampling frequency that is not available from the Minas Gerais official monitoring program for Lake of Ingleses.

Descriptive statistical analyses were calculated to evaluate the data (log 10-transformed) distribution, using box-plot graphics, in terms of compliance with legal standards (e.g., Helsel and Hirsch 2002; Lopes et al. 2020). The ICB was calculated using Microsoft EXCEL® (Office 365), for data in the IGAM monitoring. The value of the sub-index for each variable in the index (Lopes et al. 2016) was interpolated from the suitability-for-use curve (q) for that variable. The overall index value is taken as the value of the limiting variable (Table 2 ), that is, the one with the lowest sub-index value (minimum operator). The overall index value is interpreted as follows: "Excellent" (100 $\geq$ ICB $\geq 90$ ), "Very Good" (90 > ICB $\geq 70$ ), "Suitable" (70 > ICB $\geq 50$ ), "Unsuitable" (50 > ICB $\geq 25)$ and "Very Bad" (ICB < 25) (Lopes et al. 2016).

Table 2. Example of the ICB index application (Site AV160 - Lake of Ingleses, October 2009)

\begin{tabular}{|c|c|c|c|}
\hline Attribute & Results & Sub-Index Value & Class \\
\hline $\begin{array}{l}\text { Escherichia coli [cfu } 100 \mathrm{~cm}^{-3} \text { ] } \\
\text { Cyanobacteria density [cells cm} \mathrm{cm}^{-3} \text { ] } \\
\text { pH } \\
\text { Turbidity [NTU] }\end{array}$ & $\begin{array}{c}23 \\
0 \\
6.9 \\
6.6\end{array}$ & $\begin{array}{c}100 \\
100 \\
90 \\
64^{*}\end{array}$ & $\begin{array}{l}\text { Excellent } \\
\text { Excellent } \\
\text { Excellent } \\
\text { Suitable } \\
\end{array}$ \\
\hline Overall INDEX score (minimum operator) & & 64 & Suitable \\
\hline
\end{tabular}

The minimum operator (Smith1990) aims to avoid the interference between variables during the aggregation process adopted in traditional water quality indexes (Nagels et al. 2001). For example, if all of the variables in the index were suitable except $E$. coli concentration, the water should still be rated "Unsuitable" because of that faecal contamination. A minimum operator identifies $E$. coli as the limiting variable (with the lowest sub-index), showing that the water is unsuitable for use, whereas aggregating indexes are subject to the serious flaw of returning fairly high values suggesting the water is, at least marginally, suitable for use. The adoption of the minimum operator prevents a limiting variable from being compensated for ("swamped" - Smith 1990) by others that are not limiting (Lopes et al. 2016).
For the diagnosis and management of recreational waters, international guidelines recommend the adoption of long-term assessments or "gradings" (WHO 2003; MFE/MOH 2003; EU 2006). This evaluation provides a meaningful analysis of the quality of recreational water, given the influence of seasonal factors and possible errors in reading and sampling (WHO 2001; McBride and Soller 2017). These are based on a minimum set of samples collected over a period considered representative (usually 5 years). Thus, the long-term classification for Lake of Ingleses was carried out considering the entire period of official monitoring (01/2003 to 07/2019), adopting the $80 \%$ percentile criteria (CONAMA 2000; Lopes et al. 2016), on the total final results of the ICB $(n=35)$. 


\section{Results and Discussion}

\section{Microbiological water quality}

Escherichia coli concentrations (1 to 220 cfu 100 $\mathrm{cm}^{-3}$ ), complied with the standard of $800 \mathrm{cfu} 100$ $\mathrm{cm}^{-3}$, in $100 \%$ of samplings (Fig. 2A), despite the considerable variation. Of the available data, $97 \%$ would be classified as "Excellent" (E. coli $\leq 200 \mathrm{cfu}$ $100 \mathrm{~cm}^{-3}$ ).

These results also meet the most restrictive standard demanded conducting triathlons (500 $\mathrm{cfu} / 100 \mathrm{~mL}$ for $E$. coli), adopted by ITU since 2010 (Migliorini 2019). This value refers to the "Excellent" category in European directive 2006/7/EC (EU 2006).

Van Asperen et al. (1998) argued for a more restrictive standard for the practice of triathlon and open-water swimming. They demonstrated that the risk of gastroenteritis was undesirably high among triathletes who swam in waters with an $E$. coli concentration of $355 / 100 \mathrm{~mL}$, while for values $<238 / 100 \mathrm{ml}$, the rates of incidence were comparable with non-swimmers. Rates of gastrointestinal illness were higher among athletes who swam in waters contaminated by sewage at levels above contact recreation thresholds, and the risk increased with the amount of water swallowed (Harder-Lauridsen et al. 2013).

Open water swimmers may become infected through ingestion and/or contact of the skin or mucosa with contaminated water in training and competitions. During such events, athletes could have an increased risk of contracting infections, especially due to prolonged effort (Chamberlain et al. 2019; Migliorini 2019) associated with stress hormones; drop in some specific immunity parameters, such as the concentration and activity of antigens; and the possibility of failure of local protective mechanisms of the intestinal tract and skin (Dallam et al. 2005; Migliorini 2019).

For high-performance sports (ITU 2019), the standards stipulated by CONAMA Resolution 274 (CONAMA 2000), and the ICB (Lopes et al. 2016), for $E$. coli need to be adapted for the selection and evaluation of competition venues. Thus, we recommend the adoption of the thresholds stipulated for Very Good (E. coli $\leq 400)$ or Excellent $(E$. coli $\leq 200)$ quality classes.

Despite favourable results for $E$. coli levels, Craun et al. (2005) highlight that swimming is essentially an activity of communal bathing and pathogens can be introduced by bathers themselves, especially gastrointestinal infections. Hall et al. (2017) identified a possible influence of the use of bathing suits (wetsuits) to the highest inci- dence of gastrointestinal infections among athletes. Such suits - which, by retaining water, can promote the growth of microorganisms such as bacteria and fungi. Furthermore, the handling of this equipment after the event can create and/or prolong the risk of infection, suggesting that proper washing of the suits between races would be essential (Hall et al. 2017).

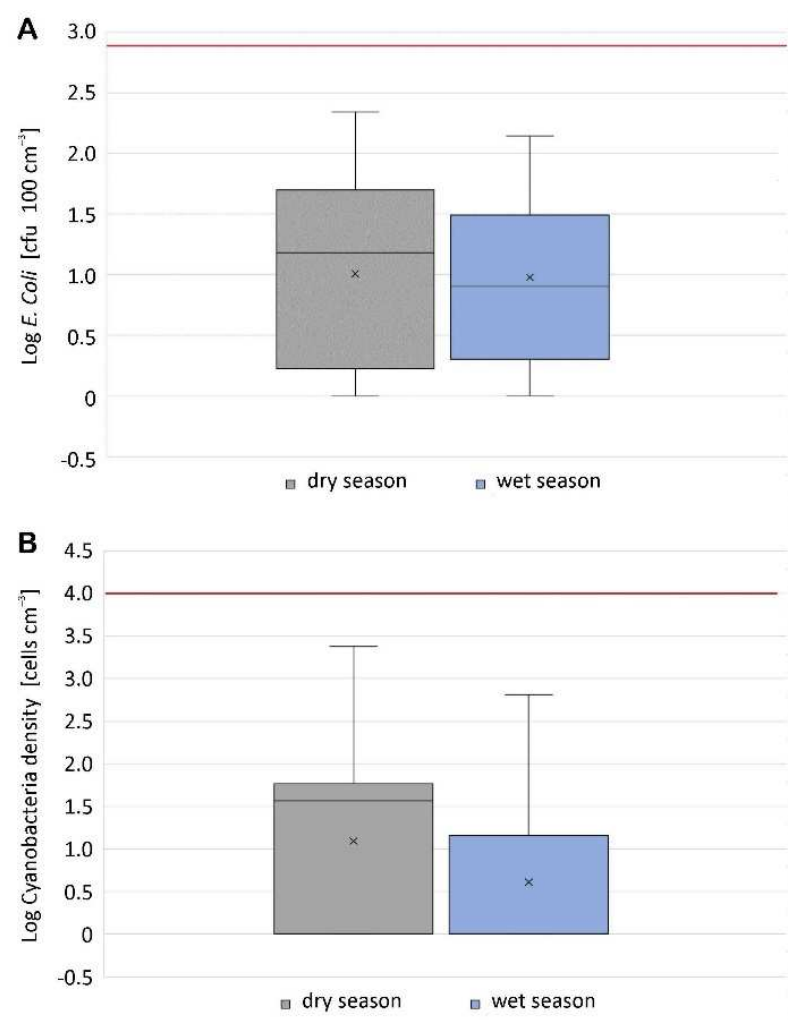

Fig. 2. Boxplots for E. coli (A) and cyanobacteria density (B). The dry season is represented by light grey boxplots and the wet season by light blue boxplots. Red lines are the thresholds for contact recreation specified by CONAMA (2000) and COPAM/CERH-MG (2008), respectively

It is known that sediments and aquatic plants can store faecal microbes, such as $E$. coli for several months, out of sun-exposure (e.g. Drummond et al. 2015). These faecal microorganisms can be incorporated back into the water column, especially during hydrological events and recreational activities (e.g. Chávez-Díaz et al. 2020). Thus, disturbance of the sediment bed of water bodies bed during swimming competitions, especially during the start and entry into the water, may entrain appreciable faecal contamination into the water column - further exposing the athletes.

Considering the risks of endemic diseases in some countries, it is essential that water quality, including sanitary and environmental conditions (health inspections), are thoroughly evaluated be- 
fore international competitions. Thus, other indicators should be considered in an integrated assessment, such as the incidence of waterborne diseases like schistosomiasis. This disease is still considered endemic in several areas of Brazil, including Minas Gerais state (Massara et al. 2008; Pinto et al. 2013), and poses a risk to athletes (Jeans and Schwellnus 1994).

For ITU, health inspections for conducting triathlon tests must consider: abnormal changes in water colour; absence of oils on the water surface or causing odours; absence of phenol odour; absence of apparent alpha blooms; absence of rodents (leptospirosis vectors); absence of litter; absence of industrial installations with cooling water discharge (risk of pathogenic amoebae associated with hot environments); absence of effluent releases or presence of houses and boats (Migliorini 2019).

The limitation in the use of traditional indicators for primary contact recreation, such as thermotolerant coliforms and E. coli, especially in recreational waters under the urban influence, can be exemplified from their low correlation with protozoa such as Cryptosporidium spp. and Giardia spp. Even in low water concentrations, these organisms have a high potential to cause gastroenteritis outbreaks among swimmers (Kramer et al. 1998). Furthermore, enteric viruses, identified even in water used for the Olympic Games in Rio de Janeiro in 2016 (Staggemeier et al. 2016), may also be present in recreational waters classified as suitable by microbiological indicators (Vieira et al. 2012).

Considering that there are no studies that have examined the effects of cyanobacteria on open water swimming athletes (Chamberlian et al. 2019), different standards are adopted for triathlon associations around the world (e.g. British Triathlon 2017). The USA Triathlon (2020) for example, follows the guidelines established by the agency responsible for the water body.

Despite the lack of Brazilian national standards for cyanobacteria density in recreational waters, the state of Minas Gerais has established the standard of 10,000 cells $\mathrm{cm}^{-3}$ for its waters (COPAM/CERH-MG 2008), and this standard was also adopted by the ICB. This limit is more restrictive than the criteria of 100,000 cells $\mathrm{cm}^{-3}$, adopted by the ITU (Migliorini 2019). Cyanobacterial cell densities from 2008 to 2019 (between 0 and 2,368 cells $100 \mathrm{~cm}^{-3}$ ), were in compliance with the local standard for contact recreation and also for international open water swimming and triathlon activities (Fig. 2B).

The low concentration of cyanobacteria observed in the Lake of Ingleses, contrasts with the situation of other reservoirs of recreational interest located in the metropolitan region of Belo Horizonte (Lopes et al. 2017, 2020) - apparently reflecting far less nutrient enrichment. In addition to the risks to human health due to exposure to cyanotoxins through ingestion, inhalation and skin contact, which can cause skin irritation or even fatalities (Carmichael et al. 2001; Codd et al. 2005; Buratti et al. 2017), the aesthetic and sensory effects (West et al. 2016) associated with algal blooms imply repulsive conditions to the general public.

\section{Physical and chemical water quality}

According to CONAMA Directive 274/2000 and ITU standards, $\mathrm{pH}$ values should be between 6 and 9 . Values outside this range may cause irritation to eyes, skin and mucous membranes (WHO 2003). It should be noted that the variation in $\mathrm{pH}$ values is related both to natural factors, such as rock dissolution, oxidation of organic matter and photosynthesis, and to anthropogenic factors, such as the discharge of domestic and industrial sewage (Lopes and Magalhăes Junior 2010).

In Lake of Ingleses, $100 \%$ of the $\mathrm{pH}$ results (Fig. 3A) complied with the limits - as observed in other aquatic environments used for primary contact recreation in Brazil (e.g., Medeiros et al. 2016; Bagattoli et al. 2018).

Turbidity results ranged from 0.5 to $13.3 \mathrm{NTU}$ over the historical series (Fig. 3B). Although CONAMA Directive 274/2000 does not specify turbidity for recreational use, the general water quality classification for the lake (Class 2 ) is based on the limit of 100 NTU (COPAM/CERH-MG 2008). However, in view of the risk of submerged threats present in the bed of water bodies (branches, rocks, sandbanks, sharp residues, litter), as well as the visualization of depth, which are affected by waters with low visibility (Lopes et al. 2016; West et al. 2016), this limit would be insufficient for the safe practice of primary contact recreation. According to Chamberlain et al. (2019), especially in water bodies surrounded by urban areas, litter may pose risks for gastrointestinal infection following water exposure.

For competitions, ITU recommends that the visual clarity of waters should be greater than a Secchi depth of $1 \mathrm{~m}$ (corresponding to a visual clarity of about $0.8 \mathrm{~m}$ - Davies-Colley et al. 2003). However, there is no visual clarity data available in the water monitoring carried out by IGAM, nor are there visual clarity standards (e.g., Secchi depth) or visual clarity (Black disc) for contact recreation in Brazil. Lopes et al. (2016) suggested 
that turbidity can be used to assess visual clarity roughly where direct measurements of visual clarity were unavailable. Thus, considering that turbidity is inversely related to visibility, around four times (Davies-Colley et al. 2003), using the Secchi disk method, the results for Lake of Ingleses varied between $30 \mathrm{~cm}$ and $8 \mathrm{~m}$ (Median $=1.7 \mathrm{~m}$ ).

Converting the visibility standard established by the ITU $(1 \mathrm{~m})$ to turbidity (NTU), through the relationship established by Davies-Colley et al. (2003), it would be necessary for the waters destined for the practice of high-performance sports to have turbidity levels equal to or less than 4 NTU (Fig. 3B). The ICB could be used as an alternative for the classification of test sites, adopting thresholds for Very Good ( $>2$ to $\leq 5 \mathrm{NTU}$ ) or Excellent ( 0 to $\leq 2 \mathrm{NTU}$ ) classes.

A 9.5

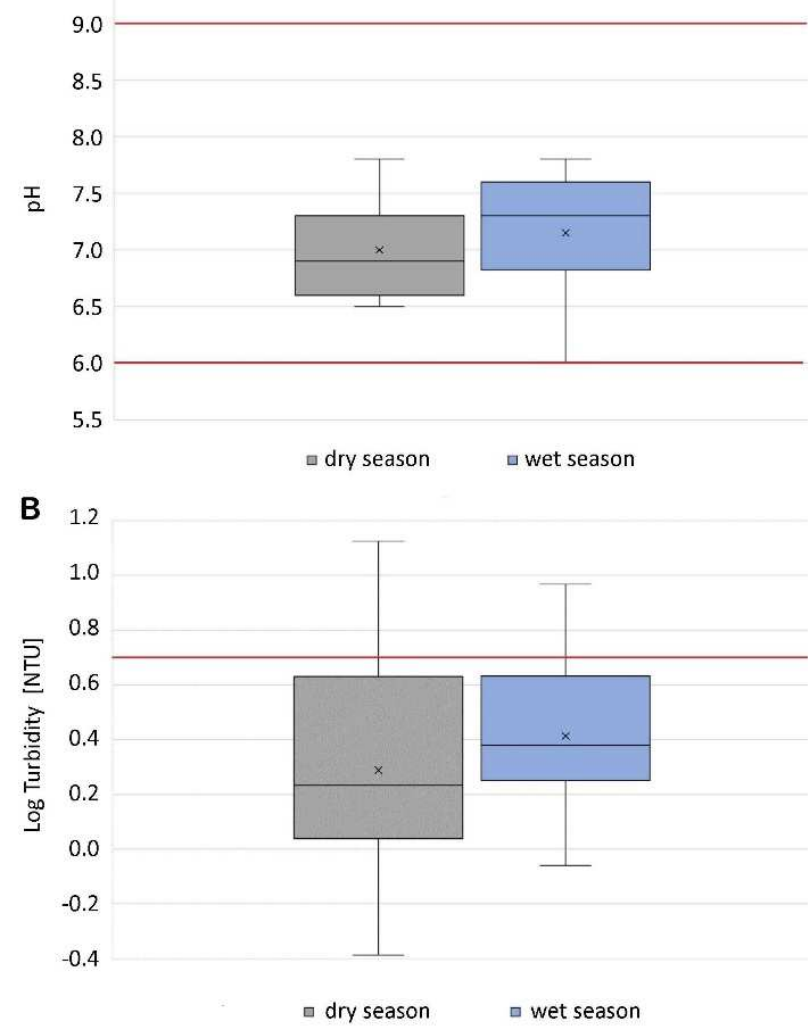

Fig. 3. Boxplots for $\mathrm{pH}$ (A) and turbidity (B). The dry season is represented by light grey boxplots and the wet season by light blue boxplots. Red lines are the thresholds for contact recreation, which, for turbidity, corresponds to the "Very Good" class in the ICB

In tropical environments, typically, high levels of turbidity and correspondingly low visual clarity are controlled by erosion of highly weathered soils, resulting from intense seasonally concentrated precipitation, as well as soil management in agricultural activities (Lopes et al. 2016). Therefore, standards for visual clarity, developed for temperate environments (e.g., oligotrophic lakes), may not be immediately applicable in tropical environments.

\section{Index of Conditions for Bathing - ICB}

According to ICB results for Lake of Ingleses (Fig. 4), the water quality for primary contact recreation was classified (48.5\%) as "Very Good" $(90>$ ICB $\geq$ 70), while conditions classified as "Excellent" (100 $\geq \mathrm{ICB} \geq 90$ ) and "Suitable" (70>ICB $\geq 50$ ), occurred, respectively, in $28.5 \%$ and $20 \%$ of the samples carried out between 2003 and 2019. Unsuitable conditions ( $50>I C B \geq 25)$ for contact recreation activities with the waters were verified only in the 04/05/2011 campaign, due to the influence of the turbidity levels on the ICB, according to the methodology of the minimum operator.

Considering the standards recommended by the ITU, the ICB classes that would be in conformity with such specificities would be Very Good or Excellent. Thus, the waters of the Lake of Ingleses were found to conform to the triathlon standards in $77 \%$ of the samplings carried out.

Water quality may be temporarily compromised by seasonal factors related to increased runoff and a consequent greater supply of suspended solids and bacteria of faecal origin (e.g., Stott et al. 2011; Von Sperling and Von Sperling 2013; Harder-Lauridsen et al. 2013; Davies-Colley et al. 2018). In areas under the influence of effluents of predominantly human origin, the highest incidences of diseases are associated with enteric viruses, while in areas impacted by contaminants of animal origin, the greatest concerns are associated with bacteria and protozoa (Milne et al. 2017). Thus, environmental monitoring agencies generally recommend that swimmers avoid contact with water after heavy or prolonged rain (McBride and Soller 2017). In the case of open water swimming competitions, ITU recently started adopting, in addition to $E$. coli concentrations and sanitary inspections, the inclusion of the forecast of heavy rains as a criterion for the classification matrix (Migliorini 2019). However, it does not specify parameters related to the probability of precipitation or accumulated volume in 24,48 or $72 \mathrm{~h}$, for example.

Even in areas with regular water quality monitoring, the traditional E. coli counting techniques require about 24 hours to obtain the results, which makes it impossible to provide information on the conditions of bathing in real-time (Davies-Colley et al. 2018). In this context, long-term evaluations (grading) are essential (WHO 2000; $\mathrm{MFE} / \mathrm{MOH}$ 2003; McBride and Soller 2017), for enabling the prior knowledge of risk factors that may interfere with water quality and, consequently, generate harmful effects on the health of users during sports activities in contact with the waters. 
Thus, adopting the $80 \%$ criterion for the general classification of the ICB (long-term), the waters of Lake of Ingleses between 2003 and $2019(n=35)$ would be classified in the "Suitable" class (ICB $\geq 50$ ).
However, such results are insufficient according to ITU standards only for turbidity, as an indicator of water transparency.

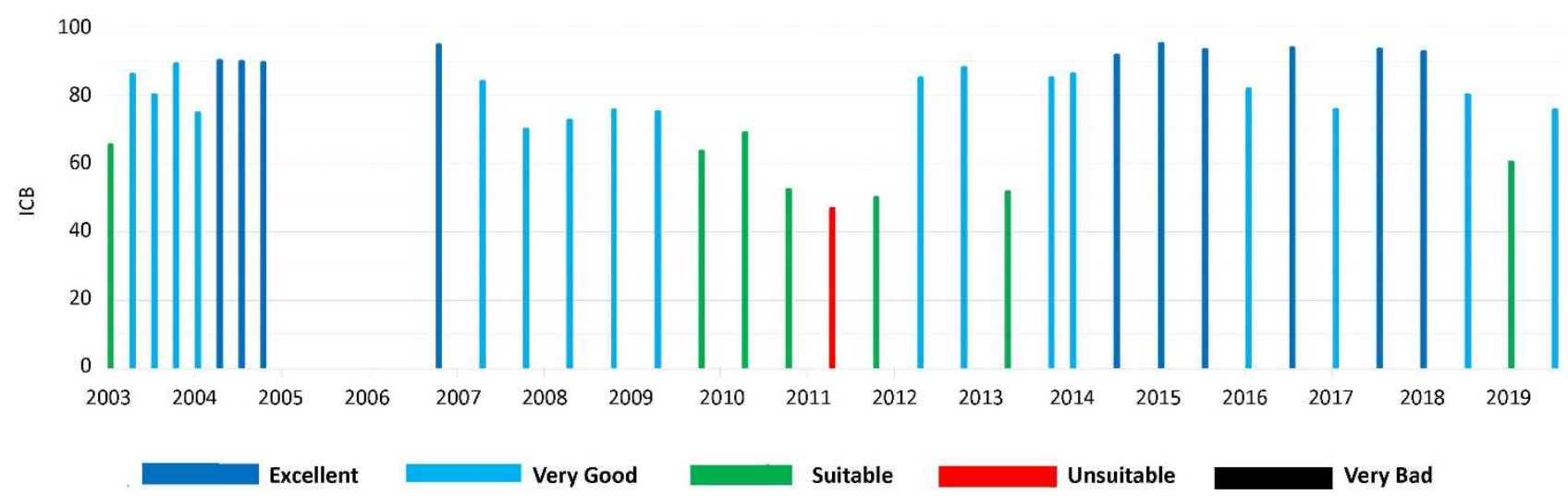

Fig. 4. Results distributions by ICB quality classes for Lake of Ingleses between 2003 and 2019

McBride and Soller (2017) emphasize that the long-term assessment should be adopted with caution, given that results unsuitable to legal standards, referring to the beginning of monitoring, could result in the lower rating of the recreational area, even after improvements in water quality in recent assessments. In addition, inherent natural conditions of tropical environments can affect the transparency and occurrence of cyanobacteria in lakes, even in areas without or with low anthropic interference.

It should be noted that the official monitoring available for Lake of Ingleses, carried out by the Minas Gerais Water Management Institute IGAM, was not developed for application in recreational waters, due to the low frequency of sampling. Regarding open water swimming competitions, ITU (Migliorini 2019) recommends water analysis at three different sampling points, the worst result being considered. Samples must be taken one year, two months before the competition, and seven days prior to the main event, and during the first day of the competition (this being considered for statistical purposes only). If the results are not in compliance, the swim section of the competition must be canceled.

\section{Conclusion}

Our results demonstrate that Lake of Ingleses complies with state, national and international standards for primary contact recreation and highperformance sports activities, considering $E$. coli levels, $\mathrm{pH}$ and cyanobacteria density. However, the visual clarity (as indicated, roughly, by turbidity), did not comply with ITU standards. This result, however, highlights the challenge of finding areas suitable for open water swimming competitions, in terms of visual clarity standards, in tropical freshwater environments, especially during periods of increased runoff.

The ICB proved to be suitable for interpreting and reporting the international standards established for triathlon, using the Very Good or Excellent quality classes. With the use of the minimum operator methodology, this index ensures that any attribute not meeting official standards will be limiting and control the overall index value. In contrast, CONAMA Directive 274/2000 presents standards only for $E$. coli and $\mathrm{pH}$, which hamstrings its direct application to primary contact in high-performance sports.

Despite the generally insufficient frequency of water quality monitoring carried out by state environmental agencies in Brazil, especially for the diagnosis and warning of unsuitable contact recreation conditions, official records are fundamental for carrying out long-term ("grading") assessments. This methodology for evaluating the historical data for long-term evaluations identifies potential areas for competition venues, as well as areas of risk to users.

However, even in areas systematically classified as suitable for contact recreation, it is recommended that before and during high-performance aquatic sporting events, the water quality is assessed through a specific monitoring program in accordance with ITU guidance. This will 
increase the chance of identifying risks of sporadic events that may temporarily impair water quality.

\section{References}

Bagattoli F., Serbent M.P., Censi G., Bachmann S.A.L., 2018, Assessment of Presidente Getúlio waterfalls bathing conditions - Santa Catarina State, Brazil, Braz. J. Aquat. Sci. Technol. 22(1): 22-29.

British Triathlon, 2017, $\mathrm{SH}_{2} \mathrm{OUT}$. Water quality guidance for open water events and training sessions [online document], British Triathlon and Royal Life Saving Society UK, Loughborough, 15 pp (Accessed 30 March 2020). Retrieved from https://www. sh2out. org/documents/Resources/Orgaised\%200pen\%20 Water\%20Swimming\%20Revision\%20edited\%20002-.pdf.

Buratti F.M., Manganelli M., Vichi S., Stefanelli M., Scardala S., Testai E., Funari E., 2017, Cyanotoxins: producing organisms, occurrence, toxicity, mechanism of action, and human health toxicological risk evaluation, Arch. Toxicol. 91(3): 1049-1130.

Carmichael W.W., Azevedo S.M., An J.S., Molica R.J., Jochimsen E.M., Lau S., Rinehart K.L., Shaw G.R., Eaglesham G.K., 2001, Human fatalities from cyanobacteria: chemical and biological evidence for cyanotoxins, Environ. Health Perspect. 109(7): 663668.

[CSUL] Centralidade Sul, 2015, RIMA - Relatório de Impacto Ambiental (Environmental Impact Report), CSul Desenvolvimento Urbano, Nova Lima, 97 pp (in Portuguese).

Chamberlain M., Marshall A.N., Keller S., 2019, Open water swimming: Medical and water quality considerations, Curr. Sports Med. Rep. 18(4): 121-128.

Chávez-Díaz L.V., Gutiérrez-Cacciabue D., Poma H.R., Rajal V.B., 2020, Sediments quality must be considered when evaluating freshwater aquatic environments used for recreational activities, Int. J. Hyg. Environ. Health 223(1): 159-170.

Chorus I., Bartram J. (eds), 1999, Toxic cyanobacteria in water: A guide to their public health consequences, monitoring and management, WHO-CRC Press, Boca Raton-London-New York, 432 pp.

Codd G.A., Morrison L.F., Metcalf J.S., 2005, Cyanobacterial toxins: Risk management for health protection, Toxicol. Appl. Pharmacol. 203(3): 264-272.

[CONAMA] Conselho Nacional do Meio Ambiente, 2000, Resoluçăo CONAMA N.ş 274/2000, de 29 de novembro de 2000. Revisa os critérios de balneabilidade em aguas brasileiras (Reviews the criteria for bathing in Brazilian waters), Diário Oficial da Uniăo (DOU) 18, de 25 de janeiro de 2001, Seçăo 1: 7071 (in Portuguese).

[COPAM/CERH-MG] Conselho Estadual de Política Ambiental / Conselho Estadual de Recursos Hídricos do Estado de Minas Gerais, 2008, Deliberaçăo Normativa Conjunta COPAM/CERH-MG N.ş 1 , de 05 de maio de 2008. Dispóe sobre a classificaçăo dos corpos de água e diretrizes ambientais para o seu enquadramento, bem como estabelece as condiçóes e padrốes de lançamento de efluentes, e dá outras providęncias (Provides for the classification of water bodies and environmental guidelines for their classification, as well as establishing the conditions and standards for the release of effluents, and other measures), Diário do Executivo - Minas Gerais, de 13 maio 2008 (in Portuguese).

Craun G.F., Calderon R.L., Craun M.F., 2005, Outbreaks associated with recreational water in the United States, Int. J. Environ. Health Res. 15(4): 243-262.

Dallam G.M., Jonas S., Miller T.K., 2005, Medical considerations in triathlon competition, Sports Med. 35(2): 143-161.

Davies-Colley R.J., Vant W.N., Smith D.G., 2003, Colour and clarity of natural waters. Science and management of optical water quality, Blackburn Press, Caldwell, $310 \mathrm{pp}$.

Davies-Colley R., Valois A., Milne J., 2018, Faecal contamination and visual clarity in New Zealand rivers. Correlation of key variables affecting swimming suitability, J. Water and Health 16(3): 329-339.

Dorevitch S., Panthi S., Huang Y., Li H., Michalek A.M., Pratap P., Wroblewski M., Liu L., Scheff P.A., Li A., 2011, Water ingestion during water recreation, Water Res. 45(5): 2020-2028.

Drummond J., Davies-Colley R. ., Stott R., Sukias J.P., Nagels J.W., Sharp A., Packman A.I., 2015, Microbial transport, retention, and inactivation in streams: Acombined experimental and stochastic modelling approach, Environ. Sci. Technol. 49(13): 78257833.

Dufour A.P., Evans O., Behymer T., Cantú R., 2006, Water ingestion during swimming activities in a pool: $A$ pilot study, J. Water Health 4(4): 425-430.

Dufour A.P., Behymer T.D., Cantú R., Magnuson M., Wymer L.J., 2017, ingestion of swimming pool water by recreational swimmers, J. Water Health.15(3): 429-437.

[EU] European Union, 2006, Directive 2006/7/EC of the European Parliament and of the Council of 15 February 2006 concerning the management of bathing water quality and repealing Directive 76/160/EEC, Offic. J. Eur. Union (OJEU) L 64: 37-51.

Fewtrel L., Kay D., 2015, Recreational water and infection: A Review of recent findings, Curr. EnvirOn. Health Rep. 2(1): 85-94.

Foley R., 2017, swimming as an accretive practice in healthy blue space, Emot.Space Soci. 22: 43-51.

Hall V., Taye A., Walsh B., Maguire H., Dave J., Wright A., Anderson C., Crook P., 2017, A large outbreak of gastrointestinal illness at an open-water swimming event in the River Thames, London, Epidemiol. Infect. 145(6): 1246-1255.

Harder-Lauridsen N.M., Kuhn K.G., Erichsen A.C., Mřlbak K., Ethelberg S., 2013, Gastrointestinal illness among triathletes swimming in non- polluted versus polluted seawater affected by heavy rainfall, Denmark, 2010-2011, PLoS One 8(11): e78371.

Helsel D.R., Hirsch R.M., 2002, Statistical methods in water resources: Techniques of water resources investigations of the US Geological Survey. Book 4: Hydrologic analysis and interpretation, Chapter 3, US Geological Survay, 510 pp. 
[IGAM] Instituto Mineiro de Gestăo das Águas, 2020, Monitoramento da qualidade das águas (Monitoring of water quality) [online document] (Accessed 18 March 2020). Retrieved from http://portalinfohidro.igam.mg.gov.br/ (in Portuguese).

Jeans A., Schwellnus M., 1994, The risk of schistosomiasis in Zimbabwean triathletes, S. Afr. Med. J. 84(11): 756-758.

Kramer M.H., Sorhage F.E., Goldstein S.T., Dalley E., Wahlquist S.P., Herwaldt B.L., 1998, First reported outbreak in the United States of cryptosporidiosis associated with a recreational lake, Clin. Inf. Dis. 26(1): 27-33.

Lamparelli C.C., Pogreba-Brown K., Verhougstraete M., Sato M.I.Z., Bruni A.C., Wade T.J., Eisenberg J.N.S., 2015, Are fecal indicator bacteria appropriate measures of recreational water risks in the tropics: A cohort study of beach goers in Brazil? Water Res. 87: 59-68.

Laschefski K., Costa H.S.M., 2008, Segregaçăo social como externalizaçăo de conflitos ambientais: a elitizaçăo do meio ambiente na APA-Sul, Regiăo Metropolitana de Belo Horizonte (Social segregation like externalizing environmental problems: the elitization of the environment in the APA-Sul, Metropolitan Region of Belo Horizonte), Ambient. Soc. 11(2): 307-322 (in Portuguese, English summary).

Lopes A.M.M.B., Gomes L.N.L., Martins F.C., Cerqueira D.A., Mota Filho C.R., von Sperling E., Pádua V.L., 2017, Dinâmica de protozoários patogęnicos e cianobactérias em um reservatório de abastecimento público de água no sudeste do Brasil (Spatial and temporal assessment of sanitary aspects of public water supply reservoirs in SP, Brazil, with emphasis on cyanobacteria and cyanotoxins), Eng. Sanit. Ambient 22(1): 25-43 (in Portuguese, English summary).

Lopes F.A., Davies-Colley R., Piazi J., Silveira J.S., Leite A.C., Lopes N.I.A., 2020, Challenges for contact recreation in a tropical urban lake: Assessment by a water quality index, Environ. Dev. Sustain. 22(6), 5409-5423.

Lopes F.A., Jesus C.R., 2017, Lazer e balneabilidade: uma abordagem histórica sobre o uso recreacional das águas na sociedade (Leisure and water quality for recreational use: A historical overview of water contact recreation use in society), Caderno Geogr. 27(50): 557-572 (in Portuguese, English summary).

Lopes F.W.A., Davies-Colley R.J., von Sperling E., Magalhăes Jr A.P., 2016, A water quality index for Brazilian freshwaters, J. Water Health 14(2): 243254.

Lopes F.W.A., Magalhăes Jr A.P., 2010, Influęncia das condiçóes naturais de $\mathrm{pH}$ sobre o índice de qualidade das águas (IQA) na bacia do Ribeirăo de Carrancas (Influence of natural pH conditions on the water quality index (WQI) in the Ribeirăo de Carrancas basin), Rev. Geografias 06(2): 134-147 (in Portuguese).

Mannocci A., La Torre G., Spagnoli A., Solimini A.G., Palazzo C., De Giusti M., 2016, Is swimming in recreational water associated with the occurrence of respiratory illness? A systematic review and metaanalysis, J. Water Health 14(4): 590-559.

Massara C., Amaral G., Caldeira R., Drummond S., Enk M., Carvalho O., 2008,. Esquistossomose em área de ecoturismo do Estado de Minas Gerais, Brasil (Schistosomiasis in an ecotourism area in Minas Gerais State, Brazil), Cad. Saúde Pública 24(7): 17091712 (in Portuguese, English summary).

Massey H, Kandala N, Davis C, Harper M, Gorczynski P, Denton H., 2020, Mood and well-being of novice open water swimmers and controls during an introductory outdoor swimming programme: A feasibility study, Lifestyle Med. 1(2): e12.

Mcbride G., Soller J., 2017, Technical Background for 2017 MfE 'Clean Water' Swimmability Proposals for Rivers, NIWA Report: FWWQ1722, 36 pp.

Medeiros S.R.M., Carvalho R.G., Souza L., Barbosa A.H.S., 2016, Índice de qualidade das águas e balneabilidade no Riacho da Bica, Portalegre, RN, Brasil (Water quality index and suitability for bathing of Bica Stream, Portalegre, RN, Brazil), Rev. Ambient. Água 11(3): 711-730 (in Portuguese, English summary).

Medema G.J., van Asperen I.A., Havelaar A.H., 1997, assessment of the exposure of swimmers to microbiological contaminants in fresh waters, Water Sci. Tech. 35(11): 157-163.

Meta, 2014, Documento compromisso pela revitalizaçăo da bacia hidrográfica do Rio das Velhas: assegurar a volta do peixe e o nadar na RMBH em 2014 (Commitment document for the revitalization of the Rio das Velhas hydrographic basin: ensuring the return of fish and swimming in the $\mathrm{RMBH}$ in 2014) [online document] (Accessed 26 March 2020). Retrieved from http://www.manuelzao.ufmg.br/sobre_o_projeto/posicionamento/meta-2014 (in Portuguese).

[MFE/MOH] Ministry for the Environment and Ministry of Health, 2003, Microbiological water quality guidelines for marine and freshwater recreational areas, NZ Ministry for the Environment, Wellington, $159 \mathrm{pp}$.

Migliorini S., 2019, ITU triathlon water quality statement [online document] (Accessed 18 February 2020). Retrieved from https://www.triathlon.org/uploads/ docs/Triathlon_Water_Quality_Statement_+_Matrix.pdf.

Milne J.R., Madarasz-Smith A., Davie T., 2017, Recreational water quality monitoring and reporting in New Zealand. A discussion paper for regional and Unitary Ciuncils. NIWA Science and Technology Series No. 82, National Institute of Water and Atmospheric Research (NIWA), Wellington, $34 \mathrm{pp}$.

Nagels J.W., Davies-Colley R. J., Smith D.G., 2001, A water quality index for contact recreation in New Zealand, Water Sci. Technol. 43(5): 285-292.

Pinto H.A., Mati V.L.T., Melo A.T., 2013, The Pampulha reservoir remains a potential urban focus of schistosomiasis mansoni in Brazil: Changes in the occurrence patterns of Biomphalaria species and a new record of the parasite, Rev. Soc. Bras. Med. Trop. 46(4): 478-483. 
Pruss A., 1998, Review of epidemiological studies on health effects from exposure to recreational water, Int. J. Epidemiol. 27(1): 1-9.

Smith D.G., 1990, A better water quality indexing system for rivers and streams, Water Res. 24(10): 12371244.

Smith D.G., Croker G.F., McFarlane K., 1995, Human perception of water appearance. Clarity and colour for bathing and aesthetics, New Zeal. J. Mar. Freshwater Res. 29(1): 29-43.

Soller J.A., Schoen M.E., Bartrand T., Ravenscroft J.E., Ashbolt N.J., 2010, Estimated human health risks from exposure to recreational waters impacted by human and nonhuman sources of faecal contamination, Water Res. 44(16): 4674-4691.

Staggemeier R., Heck T.M.S., Demoliner M., Ritzel R.G.F., Röhnelt N.M.S., Girardi V., Venker C.A., Spilki F.R., 2017, Enteric viruses and adenovirus diversity in waters from 2016 Olympic venues, Sci. Total Environ. 586: 304-312.

Stott R., Davies-Colley R.J., Nagels J.W., Donnison A.M., Ross C., 2011, Differential behaviour of Escherichia coli and Campylobacter spp. in a stream draining dairy pasture, J. Water Health 9(1): 59-69.

Suppes L.M., Abrell L., Dufour A.P., Reynolds K.A.m 2014, assessment of swimmers behaviours on pool water ingestion, J. Water Health 12(2): 269-279.

USA Triathlon, 2020, Getting started [online document] (Accessed 31 March 2020). Retrivied from: https://www.teamusa.org/USA-Triathlon/USAT-forMe/Race-Directors/Sanctioning/Getting-Started.

[US EPA] United States Environmental Protection Agency, 1986, Bacteriological ambient water quality criteria for marine and fresh recreational waters. EPA440/5-84-002, 24 pp.

van Asperen I.A., Medema G., Borgdorff M.W., Sprenger M.J., Havelaar A.H., 1998, risk of gastroenteritis among triathletes in relation to faecal pollution of fresh waters, Int. .J Epidemiol, 27(2): 309315.

Vieira C.B., Mendes A.C.O., Guimarăes F.R., Fumian T.M., Leite J.P.G., Gaspar A.M.C., Miagostovich
M.P., 2012, Detection of enteric viruses in recreational waters of an urban lagoon in the city of Rio de Janeiro, Brazil, Mem. Inst. Oswaldo Cruz 107(6): 778-784.

Villaschi J., 2003, Novas modalidades de urbanizaçăo e sua inserçăo regional: o condomínio Alphaville Lagoa dos Ingleses, Nova Lima - MG (New modalities of urbanization and its regional insertion: the $\mathrm{Al}$ phaville Lagoa dos Ingleses condominium, Nova Lima - MG), [in:] Castriota L.B. (Org.), Urbanizaçăo Brasileira: Redescobertas, C/Arte, Belo Horizonte: 159-174 (in Portuguese).

von Sperling M., von Sperling E., 2013, Challenges for bathing in rivers in terms of compliance with coliform standards. Case study in a large urbanized basin (das Velhas River, Brazil), Water Sci. Technol. 67(11): 2534-2542.

West A.O., Nolan J.M., Scott J.T., 2016, Optical water quality and human perceptions: A synthesis, WIREs Water 3(2): 167-180.

[WHO] World Health Organization, 2000, Monitoring bathing water: A practical guide to the design and implementation of assessments and monitoring programs, E \& FN Spon, London, 311 pp.

[WHO] World Health Organization, 2001, Bathing water quality and human health: Faecal pollution, World Health Organization, Geneva, 58 pp.

[WHO] World Health Organization, 2003, Guidelines for safe recreational water environments. Vol. 1: Coastal and fresh waters, World Health Organization, Geneva, 219 pp.

Yau V., Wade T.J., Wilde C.K., Colford Jr J.M., 2009, Skinrelated symptoms following exposure to recreational water: a systematic review and meta-analysis, Water Qual. Expo. Health 1(2): 79-103.

Zmirou D., Pena L., Ledrans M., Letertre L., 2003, Risks associated with the microbiological quality of bodies of fresh and marine water used for recreational purposes: summary estimates based on published epidemiological studies, Arch.Environ. Health 58(11): 703-711. 